\title{
HOWELLS IN CARICATURE
}

\author{
BY CLARA AND RUDOLF KIRK \\ Of Rutgers University
}

In I9I I, when Walter Pulitzer was planning a small magazine named Satire, he wrote to various distinguished-and humorousEnglish and American men of letters to ask them to contribute a definition of satire to his new publication. On the inside of the cover of the first number, September 20, I 9 I I , under the heading "Letters from Eminent Humorists," he displayed the replies he had received from such men as Owen Seaman, the editor of Punch, Elbert Hubbard, the editor of The Philistine, and Robert Herrick, the novelist and professor of English at the University of Chicago. Three of these replies he reproduced in facsimile: one a typed letter from Theodore Roosevelt, another written in longhand by Andrew Lang, "The Dean of English Writers," and a third in the hand of W. D. Howells, "The Dean of American Writers."

Though Howells expressed great interest in Pulitzer's venture, he declined to contribute, because, he said, "my sword is hired out to Franklin Square"-in other words, he was under contract to give all he wrote to the House of Harper. Howells's letter pleased the editor so much that he not only published it in facsimile but also placed at the top of the page a tiny cartoon of Howells addressing himself to the Spirit of Satire, who is standing on Howells's hand. The letter ${ }^{1}$ reads as follows:

Dear Mr. Pulitzer,

April 23, I9I I.

I shall be so much interested to see Satire that I shall be almost willing to find myself satirized in it. As for the rest, I am an old condottiere, you know, and my sword is hired out to Franklin Square; (I do my best to make my unswerving fealty a virtue.

\section{Yours sincerely}

W. D. Howells.

Six months after the publication of this letter, Howells was depicted as the fourth in a series of caricatures over the caption "Sacrificial Somebodies," which Pulitzer ran as extras to many numbers of Satire. On March 2, I9I2, as Satire's contribution to the national

\footnotetext{
${ }^{1}$ We are indebted to Professor W. W. Howells of Harvard University for permission to republish this letter.
} 


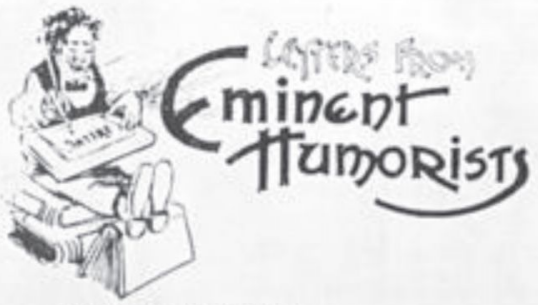

TROM THE DFAS OF EMALSA WRITILS

$$
\text { I Mavon kar }
$$$$
\text { Uent In : later lo }
$$$$
\text { s.utiu watare witing } 4
$$

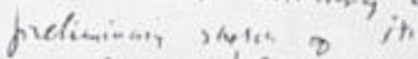

Lerten Jin the / parts tion and

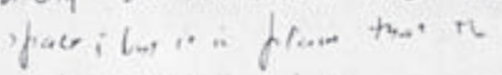

$$
\text { formet soycens sater on }
$$

Remen fins "p plober

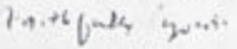

$$
\begin{aligned}
& \text { a kay }
\end{aligned}
$$

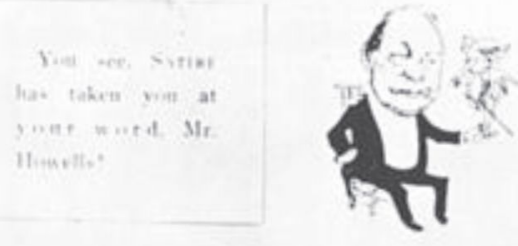

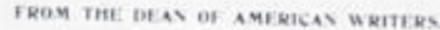

THIS FROM THE ARCH SATIRIST:
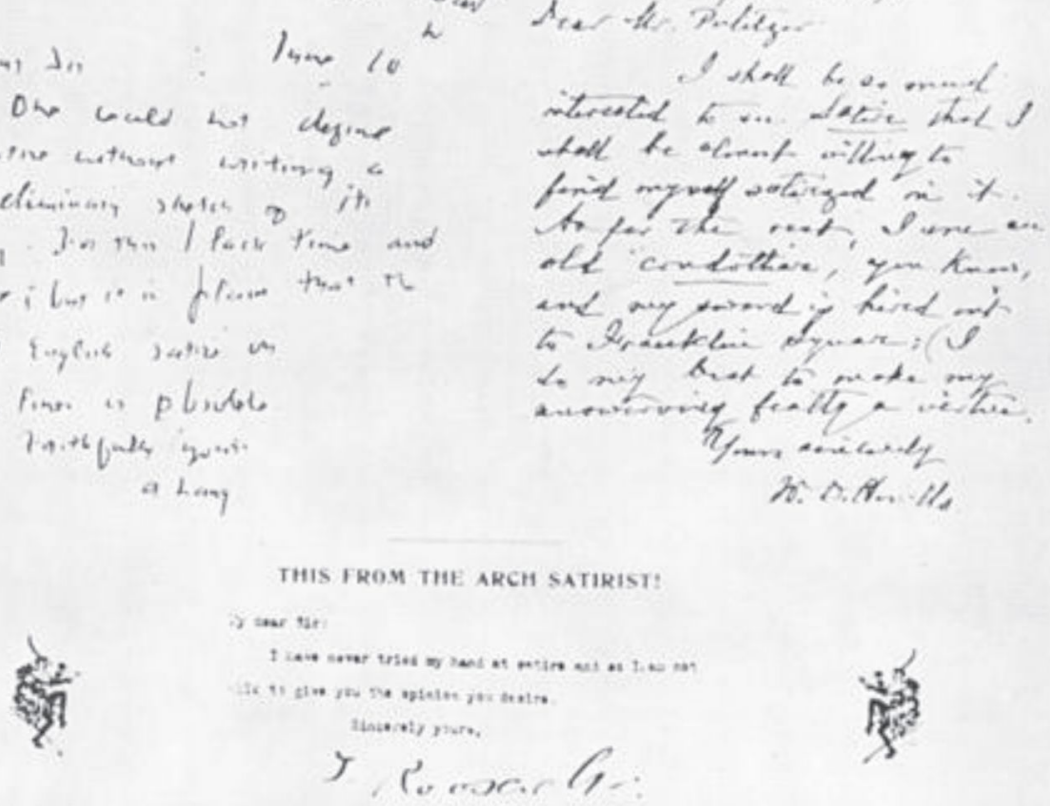

I am the happy recerwer of your levter wishins me to sive yau

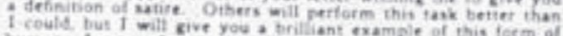
humer. Is your letiver you a brilliant example of this form of

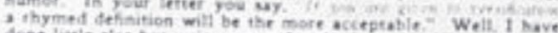

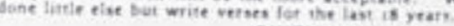
OWEN SEAMAN

Editer of Londen Panch

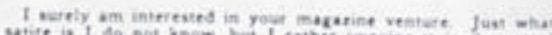

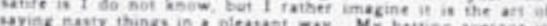

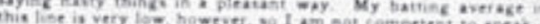

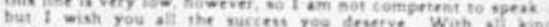
nahes ever

I am hestily in vimporky with the sorpase of your project

and much intercsed in youe succrss.

ROBERT HERRICK

Prolessoe of Enclith. Univeraty of Chicas?

The Inside Cover of Satire, September 20, I9I I 
acclaim of Howells's seventy-fifth birthday, Howells was the "Somebody" who was "sacrificed." The New York Times, the New York Sun, Harper's Weekly, and other publications, were at this time paying tribute to the nation's most well-loved author. It remained for Satire to print a genial sketch of the occupant of Harper's "Easy Chair" with his wares under his arm. The three novels singled out were considered then-and now-Howells's most permanent achievements: $A$ Modern Instance (1882), The Rise of Silas Lapham (1885), and A Hazard of New Fortunes (1890). London Films (1906) had recently appeared in the Library Edition (I9I I); perhaps it was added to the list as a bid for English subscriptions to Satire.

Since Satire and all its sketches are long ago forgotten, and, indeed, since only two or three copies are now known to have survived, we here reproduce these cartoons of Howells at seventy-five as a reminder of the affectionate regard in which the "Dean" was held by the press in the days before the first World War. A photograph of the sketches and the accompanying letter have been presented to the Rutgers University Library to add to the growing Howells collection.

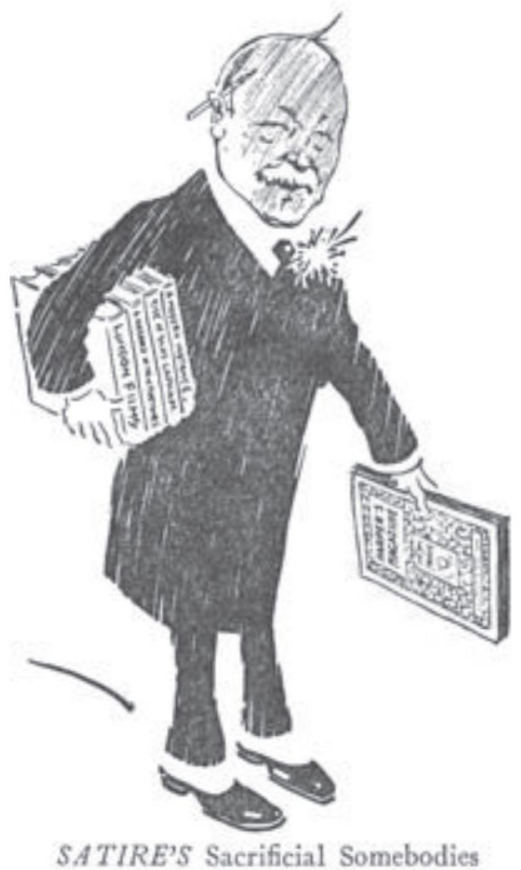

No. 4 - WILLIAM DEAN HOWELLS 